\title{
Risâletü’n-Nushiyye'de Zaman Ulaçlarının Anlamsal ve Sözdizimsel Özellikleri
}

\author{
Semantic and Syntactic Features of Tense Converbs in Risālat al-Nushiyya
}

\author{
Öğr. Gör. Dr. Ezgi ASLAN ${ }^{(D)} 1$
}

\begin{abstract}
$\ddot{\mathbf{O z}}$
Yunus Emre; günümüz Türk yazı diline büyük katkıları olan, önemli bir şairdir. Yunus Emre'nin günümüze ulaşan iki eserinden biri olan Risâletü'n-Nushiyye, on üçüncü yüzyıl Eski Anadolu Türkçesi özelliklerini taşıyan, öğretici yönü ağır basan, dini-tasavvufi bir eserdir. Eylemsiler, uzun ve karmaşık anlatıma elverişli, karmaşı dil yapıları sunar. Eylemsilerin bir türü olan ve belirteç yan tümceleri kurmaya yarayan ulaçlar; temel tümceyi zaman, neden-sonuç, amaç, tarz vb. bakımından niteler. Yunus Emre'nin sehl-i mümten̂̂ kabul edilen dilinde ulaçların kullanımının betimlenmesi, bu çalışmanın temel amaçlarından biridir. Bu çalışmada, ulaçlarla oluşturulan belirteç yan tümcelerini içeren karmaşık tümceler ele alınmıştır. Çalışmanın evrenini Eski Anadolu Türkçesi dönemi eserleri, örneklemini ise Yunus Emre'ye ait bir eser olan Risâletü'n-Nushiyye oluşturmaktadır. EAT'deki ulaçlar; Gülsevin (2011, s. 125-133)'den tespit edilmiş ve bu ulaçlar, RN üzerine en son ve güncel çalışma olan Boz (2017)'un hazırladığı Risâletü'n-Nushiyye (Öğüt Kitabı)'nin Fatih nüshasında taranmıştır. Çalışma RN'deki zaman ulaçları ile sınırlandırılmıștır. Temel ișlevi koşul tümceleri oluşturmak olan ancak RN'de zaman işlevinde de kullanılan $-s A$ biçimbirimi ile EAT gramerlerinde durum ulacı olarak işaretlenen -ken biçimbirimi de bu çalışmanın kapsamına alınmıştır. Taranan eserde tespit edilen ulaçların yan ve temel tümce eylemlerinin birbiriyle etkileşimi, eylem özellikleri, tümce işlemcileriyle (görünüş, kip, zaman, özne uyumu, olumsuzluk) olan etkileșimleri gibi sözdizimsel özellikleri ile anlamsal özellikleri incelenmiștir.
\end{abstract}

Anahtar Sözcükler: Yunus Emre, Risâletü'n-Nushiyye, ulaçlar, yan tümce, Eski Anadolu Türkçesi, dilbilim

Makale Türü: Araştırma

\begin{abstract}
Yunus Emre is an important poet who has made great contributions to today's Turkish written language. Risālat al-Nushiyya, one of the two works of Yunus Emre that has survived, is a religious-mystical work with a predominant instructive aspect. Non-finite verbs offer complex language structures suitable for long and complex narration. Converbs, which are a type of verbs and are used to form adverbial clauses; time, cause-effect, purpose, style, etc. One of the main aims of this study is to describe the use of converbs in Yunus Emre's language, which is accepted as sahl mumtani. In this study, complex sentences containing adverbial clauses formed with converbs in Risälat al-Nushiyya (RN) are discussed. It was determined from Gülsevin (2011, s. 125-133) and these converbs were scanned in the Fatih copy of Risālat al-Nushiyya (Book of Advice) prepared by Boz (2017), the latest and current study on RN. The study is limited to the tense converbs in $\mathrm{RN}$, but the $-s A$ morpheme, whose main function is to form conditional sentences, but also used in the time function in $\mathrm{RN}$, and the -ken morpheme, which is marked as the case converb in Old Anatolian Turkish grammars, are also included in the scope of this study. The syntactic and semantic properties of the converbs detected in the scanned work, such as the interaction of the subordinate and main clause, the verb properties, the interaction with the sentence operators (aspect, mood, tense, subject agreement, negation) were examined.
\end{abstract}

Keywords: Yunus Emre, Risâletü’n-Nushiyye, converbs, subclause, Old Anatolian Turkish, linguistics

\footnotetext{
${ }^{1}$ Anadolu Üniversitesi, Rektörlük, Türk Dili Bölümü, ezgicorga@ anadolu.edu.tr

Atıf için (to cite): Aslan, E. (2021). Risaletü'n-Nushiyye'de zaman ulaçlarının anlamsal ve sözdizimsel özellikleri. Afyon Kocatepe Üniversitesi Sosyal Bilimler Dergisi, 23(Yunus Emre ve Türkçe Özel Sayısı), 255-265.
} 
Paper type: Research

Giriş

Kolay ve sade göründüğü hâlde bulunup söylenmesi ve taklidi zor olan söz söyleme sanatına sehl-i mümtenî adı verilir (Devellioğlu, 2005, s. 930). ${ }^{2}$ Bu sanatın en eski ve önemli temsilcilerinden biri de Yunus Emre'dir. Geniş bir kitleye hitap edebilen ve bunu sözcüklerin ardına derin anlamlar yükleyerek yapan Yunus Emre'nin dili ile ilgili yapılan her bir çalışmanın, onun bu dil kullanımının inceliklerini keşfetmeye katkıda bulunacak olması kuşkusuzdur.

Eylemsilerin ve eylemsiler özelinde ulaçların temel niteliği, uzun ve karmaşı anlatıma elverişli dil yapıları sunabilmesidir. Temel tümceyi zaman, neden-sonuç, amaç, tarz vb. bakımından niteleyen ulaçların Yunus Emre'nin kısa ve özlü dilindeki kullanımının incelenmesi ve uzun anlatımlara olanak sunan bu yapıların Emre'nin dilindeki yansımalarının betimlenmesi; bu çalışmanın temel amacıdır.

\section{Ulaçlar}

Adeylemler, ortaçlar ve ulaçlar; temel işlevi yan tümce oluşturmak olan eylem biçimleridir. Bunların içinde temel tümceyi zaman, tarz, neden-sonuç, amaç vb. bakımından niteleyen ulaçlar; eylemlere ulaç eki olarak da adlandırılan belli biçimbirimlerin getirilmesiyle oluşturulur ve belirteç yan tümceleri oluştururlar. Ulaç yan tümceleri; özne, tümleç ve eklenti de alabilirler. Temel tümcenin seçimlik ögeleri olarak eylemin anlamını zenginleştirir ve tümceden çıkarıldıklarında tümcenin anlamını bozmaz, yalnızca daraltırlar.

Üstünova'ya göre sisteme ulaç olarak giren dil birimleri;

- Ardından gelen eyleme/yükleme belirteç göreviyle bağlanmak zorundadır.

- Belirteç göreviyle kodlanan ulaçlar, ad işletme eklerini alamaz.

- Ulaç eki son ek olmak zorundadır.

- Ulacın kurucu öge olmadığı sözcük öbekleri, yan önerme kuramaz. Yan önerme görevindeki ulaç öbekleri, temel önermenin yüklemine belirteç tümleci olarak bağlanır.

- Bitimli görünüm, ulaç olarak kullanıma engel değildir.

- Söz dizimi bakımından ulaç; bağlanacağı eylemle arasındaki tarz, zaman, mekân, sebep-sonuç, nitelik, nicelik, koşul vb. ilişkileri iletme yetisine sahip dil aracıdır (2016, s 193).

Ulaçları yapısal olarak ele alan çalışmalarda bu yapıların temelde ikili sınıflandırıldığı görülür. Tiken, basit ulaçlar ve birleşik ulaçlar (1999); Lewis, eylem köklerine eklerin eklenmesiyle yapılan ulaçlar ile ortaçlar, zaman tabanları (tensebase) veya adeylemlerden yapılan ulaçlar (2000); Gülsevin, aslî ve birleşik olarak (2001); Korkmaz, gerçek zarf fiiller, ad-fiil ve sifat-fiillerle kurulan zarf-fiiller ve değişik yapıdaki zarf-fiiller (2009) olarak ve Boz (2012); asıl ulaçlar, ortaçtan türetilen ulaçlar, ad-eylemden türetilen ulaçlar ve (i-/ol-) yardımcı eylemi ile kurulan ulaçlar olarak sınıflandırmıştır.

\subsection{Eski Anadolu Türkçesinde Ulaçlar}

Yunus Emre'nin eserlerini de kapsayan dönem, Eski Anadolu Türkçesi ${ }^{3}$ olarak adlandırılmıştır. X. yüzyıldan itibaren Orta Asya'dan batıya göç eden Oğuzların, XII. yüzyılın sonlarında kendi lehçelerine dayalı olarak Anadolu'da kurup geliştirdikleri edebî yazı diline Eski Anadolu Türkçesi (=EAT) denilmektedir (Gülsevin ve Boz, 2013, s. 1). Türk boylarının arasında en kalabalık ve askerî ve siyasi olarak da önemli bir yer tutan Oğuzların dili, XIII.

\footnotetext{
${ }^{2}$ Ayrıntılı bilgi için bk. Mengi, (2000), Saraç, (2007).

${ }^{3}$ Eski Anadolu Türkçesi adlandırmasının yanı sıra Eski Anadolu Oğuzcası, Eski Oğuzca, Eski Osmanlıca, Eski Türkiye Türkçesi terimleri de alanyazında kullanılmaktadır.
} 
yüzyıldan günümüze kadar kesintisiz olarak ürünler verilen bir dil olagelmiştir. Anadolu'daki Oğuzca üç tarihî döneme ayrilabilir (Gülsevin ve Boz, 2013, s. 4):

1. Eski Anadolu Türkçesi (ve ağızları)

2. Osmanlı Türkçesi (ve ağızları)

3. Türkiye Türkçesi (ve ağızları)

Eski Anadolu Türkçesi ve ağızları ise yine üç döneme ayrılmaktadır (Gülsevin ve Boz, 2013, s. 5):

1. Selçuklu Dönemi

2. Beylikler Dönemi

3. Osmanlıcaya Geçiş Dönemi

Yunus Emre'nin eserleri EAT’nin Selçuklu Dönemine aittir. Selçuklular Döneminde Arapça ve Farsçanın yazı dili olarak geçerli olduğu kadar Türkçe eserlerin de verildiği görülmektedir (Gülsevin ve Boz, 2013, s. 5). Sultan Veled, Şeyyad Hamza, Hoca Dehhani, Ahmet Fakih gibi yazarların yanı sıra Yunus Emre'nin eserleri de bu döneme aittir.

EAT'de ulaçlar ${ }^{4}$; zaman ulaçları, durum ulaçları, şart ulaçları ve bağlama ulaçları olmak üzere dört çeşittir (Gülsevin, 2011, s. 125-133) (Tablo 1):

Tablo 1. Eski Anadolu Türkçesinde ulaçlar

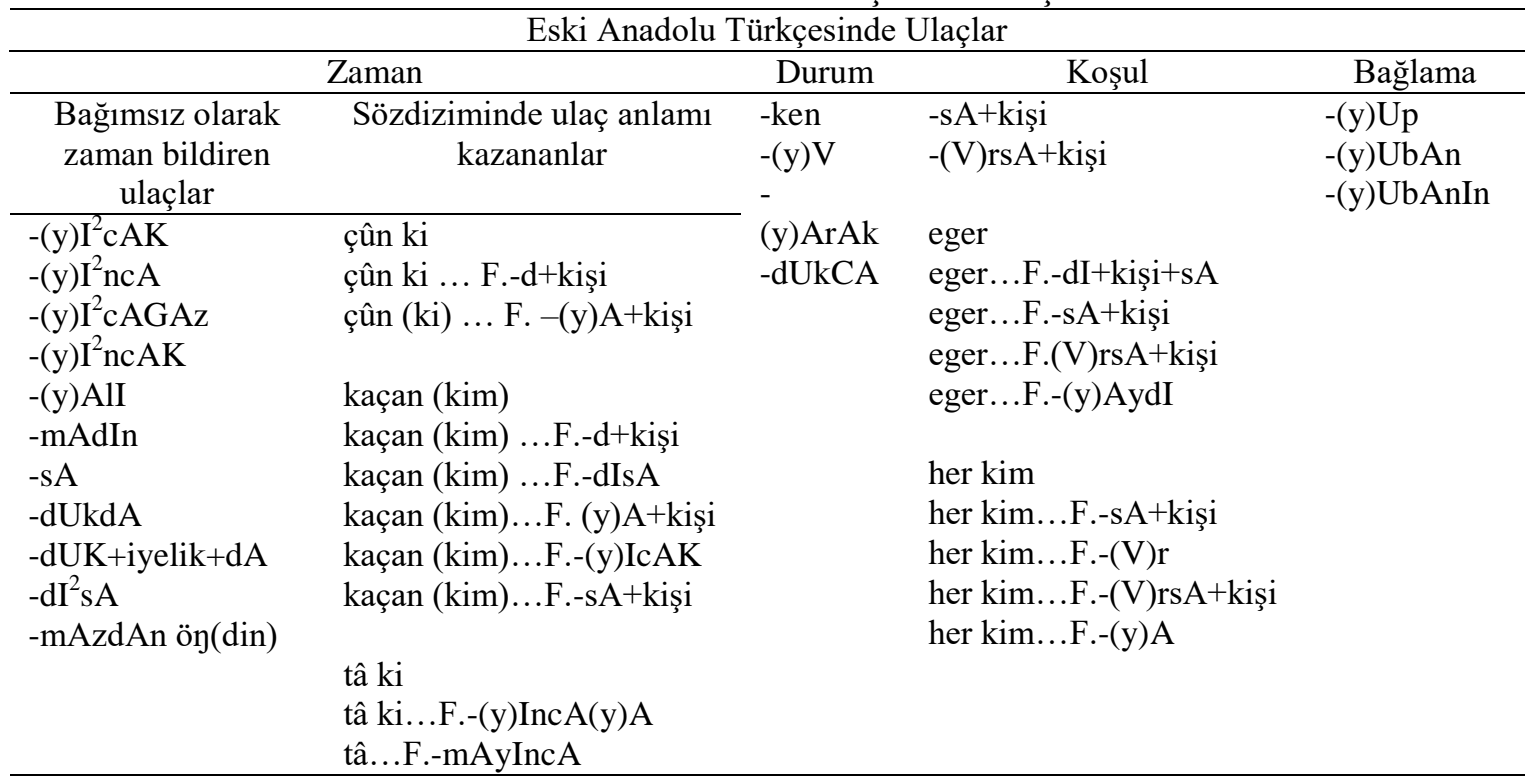

\section{Yunus Emre ve Risâletü'n-Nushiyye ${ }^{5}$}

Yunus Emre'nin iki eseri günümüze ulaşmıştır. Bunlardan biri Divan diğeri ise Risâletü'n-Nushiyye (RN)'dir. Risâletü'n-Nushiyye, dini-tasavvufi bir eserdir. Öğretici yönü ağır basar. Mesnevi nazım türünde yazılmıştır. Eserin vezni; giriş bölümündeki ilk 13 beyit (fâilâtün/fâilâtün/fâilün) kalıbındadır. Mensur kısımdan sonra gelen eserin asıl bölümün vezni ise (mefâtlün/ mefâtlün/feûlün) kalıbındadır.

Eserin yeni harflerle basımı birkaç defa yapılmıştır. Bilinen en meşhur ve bilimsel olan yayınlar; (Toprak 1933-34), (Gölpınarlı 1965), (Günay Horata 2004) ve (Tatc1 2008)'dir. Eserin bütününü ortaya çıkaran bu çalışmalardan başka, eseri çeşitli yönleriyle inceleyen birçok bilimsel araştırma vardır.

\footnotetext{
${ }^{4}$ Zarf-fiil, gerundium, bağ-eylem, bağ-fiil vb. terimlerle birlikte bu çalışmada ulaç terimi kullanılmıştır

${ }^{5}$ Eser ile ilgili ayrıntılı bilgi için bk. Boz (2017).
} 
Yunus Emre, eserini giriş bölümü hariç olmak üzere beş bölümde işlemiştir. Her bir bölümde ayrı bir konu vardır. Eser; giriş (1-13. beyitler arası ve XXIX satırlık mensur kısım), nefis ve $r h^{6}$ (14-82. beyitler), kendini beğenme ve alçak gönüllülük ${ }^{7}$ (83-180. beyitler aras1), öfke ve sabır $^{8}$ (181-302. beyitler arası), kıskançlık-cimrilik ve cömertlik ${ }^{9}$ (303-438. beyitler arası) ve dedikodu-iftira ve doğruluk ${ }^{10}$ (439-562. beyitler arası) bölümlerinden oluşmaktadır.

\section{3. Çalışmanın Amacı ve Yöntemi}

Aynı ya da benzer ilişkileri belirten yapılar arasındaki kullanım farklılıklarını belirleyen özelliklerin ortaya çıkarılmasının, EAT'nin betimlenmesine katkısının olacağı muhakkaktır. Bu katkının Yunus Emre'de incelenmesiyle Türk dilinin yazı dili olarak gelişimine Yunus Emre'nin katkılarının ortaya çıkarılması amaçlanmaktadır. Çalışmada betimsel araştırma yöntemlerinden doküman analizi kullanılmıştır.

\section{4. Çalıșmanın Evreni ve Örneklemi}

Bu çalışmanın evrenini Eski Anadolu Türkçesi dönemi eserleri, örneklemini ise Yunus Emre'ye ait bir eser olan Risâletü'n-Nushiyye oluşturmaktadır. Çalışmada zaman ulaçlarıyla oluşturulan belirteç yan tümcelerini içeren karmaşık tümceler ele alınmıştır. EAT'deki zaman ulaçları; Gülsevin (2011, s. 125-133)'den tespit edilmiş ${ }^{11}$, bu ulaçlar, RN'nin en son çalışması olan Boz (2017)'un hazırladığı Risâletü'n-Nushiyye (Öğüt Kitabı)'nin Fatih nüshasında taranmıştır. Taranan eserde tespit edilen zaman ulaçlarının yan ve temel tümce eylemlerinin birbiriyle etkileşimi, eylem özellikleri, tümce işlemcileriyle (görünüş, kip, zaman, özne uyumu, olumsuzluk) olan etkileşimleri gibi sözdizimsel özellikleri ile anlamsal özellikleri incelenmiştir.

\section{5. Çalışmanın Sınırlılıkları}

Çalışma RN'deki zaman ulaçları ile sınırlandırılmıştır. Temel işlevi koşul tümceleri oluşturmak olan ancak RN'de zaman işlevinde de kullanılan -sA biçimbirimi ile EAT gramerlerinde durum ulacı olarak işaretlenen -ken biçimbirimi de bu çalışmanın kapsamına alınmıştır. Taranan eserde tespit edilen ulaçların yan ve temel tümce eylemlerinin birbiriyle etkileşimi, eylem özellikleri, tümce işlemcileriyle (görünüş, kip, zaman, özne uyumu, olumsuzluk) olan etkileşimleri gibi sözdizimsel özellikleri ile anlamsal özellikleri incelenmiştir.

\section{Bulgular}

RN'de kullanılan zaman ulaçları ve anlamsal ve sözdizimsel özellikleri aşağıdaki gibidir:

\subsection{Bağımsız Olarak Zaman Bildiren Ulaçlar}

RN'de tespit edilen bağımsız olarak zaman bildiren ulaçlardan $-(y) I^{2} c A K,-(y) I^{2} n c A$, $m A d I n,-s A,-d I^{2} s A$ ve e -ken ulaç biçimbirimlerinin kullanımı şu şekildedir:

\subsection{1. $-(y) I^{2} c A K^{12}$}

Günümüz Türkiye Türkçesinde (TT) kullanılmayan bu biçimbirim, toplam sekiz örnekte tespit edilmiştir. $\mathrm{Bu}$ dizeler incelendiğinde 5'inde ol- eylemine eklendiği görülür. RN'de yardımcı eylemlerin sıklıkla kullanımının söz konusu olduğu, önceki çalışmalarda da ele

\footnotetext{
${ }^{6}$ dāstān-1 rûĥ u nefs ve mā-yataǾallaķu bihimā mine'l-aĥ̀āl "Ruh, nefis ve onlarla ilgili durumlara bağlı olan şeylerin destanı" 7 dāstān-1 kibr "Kendini beğenme destanı"

${ }^{8}$ dāstān-1 buşu yaǾnị ğażab "öfke yani hiddet destanı"

9 dāstān-1 buћl u hased "cimrilik ve kıskançlık destanı"

${ }^{10}$ dāstān-1 ğaybet ü bühtān "dedikodu ve iftira destanı"

${ }^{11}$ Bu çalıșmanın yanı sıra Tiken (2004)'in Eski Türkiye Türkçesinde Edatlar, Bağlaçlar, Ünlemler ve Zarf-Filler adlı çalıșması da EAT'deki ulaçlarla ilgili önemli bir çalışmadır. Gülsevin (2011)'de yer almayıp Tiken (2004)'te yer alan -IşIn, -mAyIn, -mAzdIn ve -mAzIn biçimbirimleri de RN'de ayrıca taranmış olup bu biçimbirimler eserde gözlemlenmemiştir.

12 -(y)I I cAK biçimbirimi, Salan (2017)'ın çalışmasındaki (-1caġ/-1cah/-IçAk/-UcAk/- üçek) biçimleri ile \{-IcAgIn (> -IçAgIn)\}, \{-

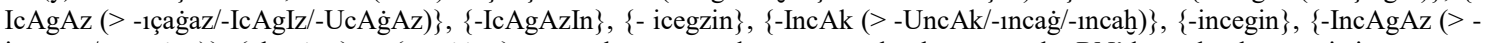
incegüz/-uncagaz) $\}$, \{ahcaġaz $\}$ ve $\{-1$ caġgaz $\}$ varyantlarına göre de taranmış olup bu varyantlar RN'de gözlemlenmemiştir.
} 
alınmıştır (bk. Datlı 2015). Bu biçimbirimin geçtiği tüm tümceler biçimce ve anlamca olumludur. Yan tümcenin öznesi dizede özellikle belirtilmediğinde anlam metnin bağlamından çıarılabilmektedir. (555)'te yan tümcenin öznesi açıken (353)'te metnin genelinden tespit edilmiştir:

(555) çırāgì1 yaķ-ıcak, ķaraju ķaçar (Çırayı yakınca karanlık kaybolur.)

(353) k,oy-ıcak yir mālun Ǿöşrini seçdi ([Allah] onu yere koyar koymaz malının onda birini ayırdl.)

Yine görünüş açısından $-(y) I^{2} c A K$ biçimbiriminin öncelik ilişkisi kurduğu söylenebilir. Bilindiği gibi zaman belirten ulaçlar temel tümce ve yan tümce arasında görünüşle ilgili anlamsal katkılar sunmaktadır. Çetintaş Yıldırım'a göre bunlar; öncelik, sonralık ve eşzamanlılık olarak sınıflandırılabilir (2005, s. 340): Öncelik belirten ulaçlar, yan tümce olayının temel tümce olayından önce meydana gelmiş olduğunu; eşzamanlılık belirten ulaçlar, iki olayın aynı zaman aralığında gerçekleşmiş ya da gerçekleşiyor olduğunu; sonralık ulaçlarıysa yan tümce olayının temel tümce olayından sonra gerçekleştiğini gösterir. Aşağıdaki dizede (361) yan tümce eylemi, temel tümce eyleminden önce gerçekleşmiştir: döndü])

(361) koy-ıcak, yir anı girü yoyuldı (Yer onu birakınca tekrar bozuldu [sözünden

$-(y) I^{2} c A K$ biçimbiriminin kullanıldığ dizelerde anlamsal olarak bir eylem ve bu eylemin doğuracağı sonuçların anlatıldığı gözlemlenmiştir ki bu da metnin genel olarak bir öğüt kitabı olmasıyla da ilişkilidir.

\subsection{2. - $(y) I^{2} n c A$}

$\mathrm{Bu}$ biçimbirim RN'de 7 örnekte geçmektedir. $-(y) I^{2} c A K$ ile benzer sözdizimsel ve anlamsal özelliklere sahiptir. $\mathrm{Bu}$ biçimbirimin olumsuz eylem çekimleriyle de kullanımı gözlemlenmiştir. $\mathrm{Bu}$ tür örneklerde öncelik görünüşüyle birlikte temel tümce eyleminin gerçekleşmesinin yan tümce eyleminin gerçekleşmesine bağlı olduğu koşul anlamı da söz konusudur. Koşul anlamı soru tümcesi tercih edilerek güçlendirilmiştir. Yan tümce olumsuzsa temel tümce de gerçekleşmez:

(460) ķaçan genc bulasın yer ķaz-ma-(y)-ınca

ya ķalb śāfṭ mi olur ķı-ma-(y)-ınca

(Yeri kazmayınca nasll hazine bulabilirsin; klzmayınca [gayret göstermeyince] kalp, safi [temiz] olabilir mi?)

(409) Ћānümān bekleyen görmeye anı

ķo-ma-(y)-ınca temām fānI cihanı

(Geçici dünyayı tamamen terk etmeyip ev bark derdinde olan, Allah'ı göremez.)

Hem $-(y) I^{2} c A K$ hem de $-(y) I^{2} n c A$ ulaçlarının geçtiği karmaşık tümceler incelendiğinde temel tümcenin eyleminin geniş/şimdiki zaman ya da geçmiş zaman çekimli olduğu görülür. Temel tümcenin eylem çekimi geçmiş zaman olduğunda bir olay ve bu olayın sonuçları belirtilir, geniş ya da şimdiki zaman çekimli eylemlerin olduğu dizeler de uyarı niteliği taşımaktadır. $\mathrm{Bu}$ yapıların da eserin ögüt verici temel niteliğine uyumlu olduğu söylenebilir. Yine $-(y) I^{2} c A K$ ve $-(y) I^{2} n c A$ ulaçlarının geçtiği tümcelerde Palmer (2001)'in önerme kipliğ $i^{13}$ başlığı altında ele aldığı kiplik türleri yer alır. Önerme kipliği (propositional modality), konuşucunun önermenin gerçekliğine ilişkin aktarımı ya da önermenin gerçekliğine dair tutumunu yansitır. (353)'te Palmer'ın sınıflandırmasına göre çıkarım (deductive) kipliği söz konusudur. "kıyamaz virmege, cānına geçdi" dizesi, vermeye kıyamama nedeniyle ilgili çıkarım

${ }^{13}$ Kiplik ile ilgili terminoloji Türkçeleştirilirken Kamacı Gencer (2019) ve (2020)'den yararlanılmıştır. 
içermektedir. (460)'ta ise ihtimal kipliği (speculative modality) söz konusudur. Hazine bulma ihtimali yer kazmak ile ilişkilendirilmiştir.

(353) ķoyıcaḳ yir mālun Ǿöşrini seçdi

ķıyamaz virmege cānına geçdi

(Allah) onu yere koyar koymaz malının onda birini ayırdı fakat ona çok ă̆ır geldi, vermeye kiyamadl.

(460) k ķaçan genc bulasın yer kazmayınca

ya ķalb śāft mi olur kızmayınca

(Yeri kazmayınca nasıl hazine bulabilirsin; kizmayınca (gayret göstermeyince) kalp, safi [temiz] olabilir mi?)

\subsection{3. -mAdIn}

RN'de bu ulacın geçtiği 5 örnek bulunmaktadır. Bu biçimbirim; yan tümcenin olumsuz, temel tümcenin olumlu olduğu ulaçlı yapılar oluşturur. Temel tümce eyleminin gerçekleşmesinin yan tümceye bağlı olduğu bir görünüş anlamı kazandırır. Yukarıda da belirtilen diğer zaman ulaçları, temel tümceye öncelik anlamı kazandırırken bu biçimbirim sonralık anlamı kazandırır; bu bazen yan tümcede ulaçlı bildirilen eylemin hiç gerçekleşmemesi anlamına da gelmektedir. (28)'de "1rılmadın tura sultān ḳatında" dizesinde uzaklaş- eyleminin gerçekleşmemesi söz konusudur. (135)’te ise “ölmeden önce” eylemin gerçekleşmesi gerekliliği söz konusudur:

(28) key arı cān gerek şeh hażretinde

Irıl-madın tura sultān ķatında

(Allah'in huzurundan uzaklaşmadan durmak için ruhun; O'nun katında çok temiz olmast gerekir.)

(135) yetis-medin sana vaǾde gözün aç

hevā vü kibr yolından beri ķaç

(Ölüm sana ulaşmadan gözünü aç; nefsin arzusundan ve kendini beğenmeden kurtul.)

6.1.4. $-s A$

-sA ekinin EAT'de ve RN'de pek çok işlevi tespit edilmiştir. Bunlardan biri de zaman işlevidir. RN'de geçen beş örnekte $-s A$ eki, günümüz TT'deki gibi $-(y) \operatorname{IncA}$, $-D I \breve{g} I$ zaman gibi zaman gösterimi sağlar:

(16) bu muћtaśar cihān iki cihanca

dükeli baḳar-ısa-n yüz bin anca

(Bütünüyle bakıldığında yüzlerce gördügün bu klsacık (küçük) dünya, iki âlemden ibarettir [gönül ve nefis]).

(17) Ǿažīm cihāndurur göyül cihanı

seni izler-ise-n bulasin an

(Gönül dünyası, büyük bir âlemdir; sen kendine bakarsan [baktığında] onu bulursun.) 
EAT'deki diğer tüm zaman ulaçlarından farklı olarak $-s A$ biçimbirimi, kişi biçimbirimlerini de alabilir. Bu nedenle de bazı çalışmalarda ulaç (zarf-fiil) başlığından ayrı olarak ele alınır. ${ }^{14}$

Bunların yanı sıra zaman başlığında ele alınamayacak başka bir işlev daha tespit edilmiştir. Göksel ve Kerslake'te de ele alınan bu yapılar, evrensel koşul tümcesi (universal condition clause) olarak adlandırılmıştır çünkü bu tümcelerin (soru ifadesinin "hangisi" olduğu durumlar dışında) kapsadığı koşul aralığının bir sınırı yoktur (2006, s. 434). Bu tümcelerin özelliği tümceye "eğer" sözcüğ̈̈ eklendiğinde tümcenin dilbilgisi dışı olması ve yan tümcede bir soru sözcüğü bulunmasıdır. RN'de bu işlevde 46 örnek bulunmaktadır. Bu örneklerde geçen soru sözcükleri neyi, niçe, kanda, nireye, ne deĐlü, ne, kime, kimde, nerede, ne var, ne kim, neye, nirede, kimüy'dür.

(197) śaķınġıl buşudan ki gizlüdür ol

nerede sizmesey anda urur yol

(Öfkeden sakın, o gizlenir; tahmin etmediğin yerde yolunu keser.)

(268) kime śabr olsa dünyāda müyesser

aja hak̦ viriserdür mülk-i dIger verecektir.)

(Kime bu dünyada sabır kolay gelirse Allah ona diğer mülkü (ahirette cenneti)

(319) hasedden kişi ne fāyide görür neye kim lāyıḳısạ tạrı virür

(İnsan kıskançlıktan ne yarar görebilir? Neye lâyıksan Allah onu verir.)

Bu tür kullanımlar da eserin amacına hizmet etmektedir çünkü koşul aralığının belirgin olmamas1, eserde hitap edilen hedef kitleye verilen ögütlerin tüm durumlarda doğruluğunu varsayar. Dolayısıyla dinî-tasavvufi eserlerde bu tür kullanımların sık görülebileceği söylenebilir. ${ }^{15}$

\subsection{5. - $-d I s A$}

$\mathrm{Bu}$ biçimbirimin iki örneği yer almaktadır. Yukarıda belirtilen evrensel koşul tümcesi özelliği bu biçimbirimde de görülmektedir. Göksel ve Kerslake'e göre bu tümcelerin çarpıcı bir özelliği, $-s A$ 'nın çeşitli sözlü -(y)sA kombinasyonlarıyla birbirinin yerine geçmesidir (2006, s. 434). -dIsA biçimbirimi de bu kombinasyonlardan biridir:

(276) niçe çag̉ır-dısa ün łaşra çıkmaz

ķodı çag̉ırmaġı ayruķ çağırmaz

(Ne kadar bağırdıysa sesi dışarı çıkmadı; bağırmayı bıraktı artık bağırmaz.)

(383) kimün kim buhl ol-dıyısa hāli

elin urmaġa māla yoķ mecali

(Kim cimri durumuna düşerse malına dokunmaya gücü yoktur. [Malından kimseye vermez.]).

\subsection{6. - ken}

EAT gramerlerinde durum ulacı olarak geçen bu ulacın RN'de zaman ve görünüş işlevi de mevcuttur. Toplam altı örnekte -ken biçimbirimi, temel tümce eylemiyle yan tümce eylemi

\footnotetext{
${ }^{14}$ Bu konudaki tartışmalar için bk. Gülsevin (1990), Karahan (1994).

${ }^{15}$ Dinî-tasavvufi metinlerde kiplik incelemesi örneği olarak Üzüm (2019), bu alandaki önemli çalışmalardan biridir.
} 
arasında görünüş bakımından eşzamanlılık ilişkisi kurar. Kılınış bakımından temel tümce eylemlerinin edim, yan tümce eylemlerinin de edim ya da erişme olduğu gözlemlenmiştir:

(297) śabırla vardı ol miǿrāca varan

diri-y-iken ölür śabrı başaran

(O Mir'ac'a ulaşan [oraya] sabırla ulaştt; sabrı elde eden yaşarken ölür [nefsin kötülüklerinden kurtulur]).

(335) hased odı anuyçün yaķdı anı

yörür-ken śag̉ esen döküldi ķanı

(Bundan dolayı kıskançlık ateşi onu yaktı [bitirdi]; să̆ salim yaşarken canına kıyıldı [çok ıstırap çekti]).

(355) ķo bu māl eksilince ben öleyin

gözüm görür-iken nice vireyin

([Karun] "Bu mal eksilirse bırakın beni öleyim; gözüm görürken nasıl [malımdan] verebilirim." dedi).

\subsection{Sözdiziminde Ulaç Anlamı Kazananlar}

\subsection{1. çün(kim)}

$\mathrm{Bu}$ başlıkta ele alınan ulaçlar, sözdiziminde belli yapıların bir araya gelmesiyle ulaç işlevi kazanırlar. RN'de bu yapılardan 9 örnek gözlemlenmiştir. Bu yapılar;

çü(n)(ki) ... eylem +görülen geçmiş zaman+3. teklik kişi biçiminde tespit edilmiştir.

od dahı geldi vü ķızdurdı anı

çünki ķızdı cisme ulaş-dı canı

(Ateş de geldi ve onu ısıttı; ısınınca ruhu vücuda girdi.)

(256) çü cāsûs bu sözi Ǿaḳla ir-ür-di

niçe kim varıdı ћaber degürdi

(Haberci bu sözü akla ulaştırdıktan başka kim varsa [onlar da] haber getirdi.)

(170) çü maǾmûr ol-dı şehrile vilayet

şād oldı dostumuz düşmānumuz māt

(Şehir ve memleket bayındır olunca dostumuz mutlu, düşmanımız [ise] perişan oldu.)

Yalnızca bir örnekte bu yapı farklı1ık göstermektedir. Bu örneğe göre bu ulaç yapısı çü.... ad+iyelik biçimindedir. Diğer tüm örneklerde duyum kipliği (sensory modality) anlamı ön plandayken (115)'teki tek örnekte ihtimal (speculative) kipliği söz konusudur:

(115) çü sensin düşmen-üy dostuy kim ola

ki yavuz hûdurur sana ĥā̄le

(Düşmanın kendin olunca dostun kim olabilir; sendeki [gerçekleri görmeyi engelleyen] perde kötü huydur.)

\subsection{2. kaçan kim}

$\mathrm{Bu}$ sözdizimsel yapının yalnızca iki örneğine rastlanmıştır. Bu yapı da evrensel koşul tümceleriyle uyum gösterir:

(267) ķaçan kim olasın bu śabrıla sen 

olmazsin]).

Ǿacebdür olasin śoyra peşı̇ān

(Sen bu sabır ile her ne zaman [birlikte] olursan sonra pişman olman gariptir, [pişman

(510) ķaçan kim göz göyülden toġru baka

işitmez ķulag̉una haķķı çaka

(Göz ne zaman gönülden doğru bakarsa [o zaman] sag்ır kulag்ına dog்ruyu duyurur.)

\section{Sonuc}

Tablo 2'de bulgular, genel olarak şu şekilde özetlenmiştir:

Tablo 2. Risâletü'n-Nushiyye'de zaman ulaçlarının anlamsal ve sözdizimsel özellikleri

\begin{tabular}{|c|c|c|c|c|}
\hline Biçimbirimler & Olumsuzluk & Görünüş & Kip & Kişi \\
\hline$-(\mathrm{y}) \mathrm{I}^{2} \mathrm{cAK}$ & yok & Öncelik & Çıkarım & yok \\
\hline$-(y) I^{2} n c A$ & var & Öncelik & $\begin{array}{l}\text { İhtimal } \\
\text { Koșul }\end{array}$ & yok \\
\hline -mAdIn, & var & Sonralık & Zorunluluk & yok \\
\hline$-\mathrm{sA}$ & yok & $\begin{array}{l}\text { Eşzamanlılık ve Bitmemişlik } \\
\text { (Alışkanlık ve Süreklilik) }\end{array}$ & Bilgisellik & var \\
\hline$-\mathrm{dI}^{2} \mathrm{sA}$ & yok & $\begin{array}{l}\text { Eşzamanlılık ve Bitmemişlik } \\
\text { (Alışkanlık ve Süreklilik) }\end{array}$ & Bilgisellik & yok \\
\hline -ken & yok & Eşzamanlılık & - & yok \\
\hline çûn ki & yok & Öncelik & Duyum & yok \\
\hline kaçan kim & yok & - & İhtimal & yok \\
\hline
\end{tabular}

$-(y) I^{2} c A K$ ulaç biçimbirimi, görünüş açısından temel tümce ile öncelik ilişkisi kurar. Bu biçimbirimin geçtiği örneklerde yan tümcedeki eylem ile temel tümce eylemi, geçmiş veya geniş/şimdiki zaman ile çekimlenmiştir. Geçmişe dair çıkarımlar ya da bir eylem ile eylemin sonunda doğacak sonuçlar betimlenir ki bu da çıkarım (deductive) kipliğini işaret eder. Bu ulaç, kişi biçimbirimleriyle çekimlenmez ve eserde olumsuz çekim görülmemiştir ancak bu kullanımın görülmemesinin, biçimbirimin genel bir özelliği olup olmadığını söylemek için dönemin diğer eserleri de ayrıca incelenmelidir.

$-(y) I^{2} n c A$ biçimbirimi, $-(y) I^{2} c A K$ ile benzer şekilde görünüş açısından temel tümce ile öncelik ilişkisi kurduğu gibi aynı zamanda koşul yapıları da kurmaktadır. Bu tür koşul yapıları, soru tümcesi ile güçlendirilmiştir. Bu biçimbirimin olumsuz kullanımı da söz konusudur. Gerçekleştirilmeyen eylemlerin sonuçlarının ne olabileceği ile ilgili dizelerin oluşturulmasında bu yapıların kullanıldığı tespit edilmiştir. Bu yönüyle de Palmer (2001)'in sınıflandırmasında ihtimal (speculative) kipliği ön plandadır.

-mAdIn biçimbirimi, temel tümce eyleminin gerçekleşmesinin yan tümceye bağl1 olduğu bir görünüş anlamı kazandırır. Bu yönüyle koşul anlamını da içerir. - $(y) I^{2} n c A$ ve (y) $I^{2} c A K$ 'tan farklı olarak yan tümce eylemiyle sonralık ilişkisi kurar. Yan tümcedeki eylemin hiç gerçekleşmemesi durumu da söz konusudur. Dolayısıyla burada yan tümcedeki eylemin gerçekleşmeme sürerliği, temel tümcenin gerçekleşmesinin koşuludur. Kiplik olarak yeterli veri olmamakla birlikte zorunluluk kipliği (obligative) ön planda görünmektedir.

-sA eki aslında koşul anlamı taşıyan ancak RN'de zaman anlamında da kullanılan bir ulaçlı biçimbirimdir. Bu biçimbirim, diğer tüm zaman ulacı biçimbirimlerinden farklı olarak kişi biçimbirimleriyle de kullanılabilmektedir. $-s A$ biçimbiriminin yine zaman ile iç içe geçmiş olarak evrensel koşul tümcesi yapıları (universal condition clause) RN'de sayıca fazla gözlemlenmiştir. Bu tümcelerin yapısal özelliği tümceye "eğer" sözcüğü eklendiğinde tümcenin dilbilgisi dış1 olması ve yan tümcede bir soru sözcüğü bulunmasıdır. Bu örneklerde geçen soru sözcükleri neyi, niçe, kanda, nireye, ne dẹlü, ne, kime, kimde, nerede, ne var, ne kim, neye, nirede, kimüy'dür. Koşul aralığının belirgin olmaması, eserin genel anlamsal özelliği itibarıyla 
verilen öğütlerin her koşulda doğruluğunu varsayar. Dini-tasavvufi eserlerde bu tür evrensel koşul tümceleleriyle ilgili yapılacak ayrıca bir çalışma da bu alanda ilginç bulgular sunacaktır.

$-s A$ eki ile benzer anlamsal ve sözdizimsel özelliklere sahip olan - $d I s A$, evrensel koşul tümcelerinin çarpıcı bir özelliği olan -sA'nın çeşitli $-(y) s A$ kombinasyonlarıyla birbirinin yerine geçtiği örneklerden biri olarak görünmektedir.

EAT gramerlerinde durum ulacı eki olarak betimlenen -ken biçimbiriminin RN'de zaman ulacı işlevinde kullanıldığı görülmüştür. Görünüş olarak eşzamanlılık belirten bu biçimbirimin geçtiği temel ve yan tümcede eylemlerin beklendiği üzere edim ya da erişme kılınışında olduğu gözlemlenmiştir. Kiplik açısından özellikle belirginleşen bir tür tespit edilmemiştir.

Sözdiziminde ulaç anlamı kazanan yapılar da $-(y) I^{2} n c A$ ve $-(y) I^{2} c A K$ ile benzer şekilde öncelik görünüşündedir. $\mathrm{Bu}$ yapılar, Gülsevin (2011)'de de belirtildiği gibi çü(n)(ki) ... eylem+görülen geçmiş zaman+3. teklik kişi olarak tespit edilmiştir. Bu biçimde tespit edilen örneklerde duyum kipliği (sensory modality) görülmekle birlikte yalnızca bir örneği görülen çü ... ad+iyelik yapısında ihtimal (speculative) kipliği söz konusudur. Kaçan kim yapısı ise yalnızca iki örnekte görülmekle birlikte sonralık görünüşünde olduğu düşünülmüştür.

RN'de zaman anlatan ulaçların önemli ölçüde koşul işleviyle birleştiği örnekler sıkça görülmüştür. Burada zaman ve koşul ilișkisinin de ayrıca ele alınması bu ulaçlarla ilgili farklı bulguların tespitini sağlayacaktır.

\section{Yorumlar}

$\mathrm{Bu}$ çalışmadaki betimlemeler, yalnızca bu eser özelinde olduğu için bu tespitlerin ve yorumların Yunus Emre'nin çağdaşı olan diğer şairlerde ve dini-tasavvufi diğer eserlerde de ele alınması, bu çalışmadaki bulguları güçlendirecektir.

\section{Kaynakça}

Boz, E. (2012). Türkiye Türkçesi biçimsel ve anlamsal işlevli biçimbilgisi (Tasnif Denemesi). Ankara: Gazi Kitabevi.

Çetintaş Yıldırım, F. (2005). Türkçede zaman anlatan ulaçların görünüş özellikleri. Dil ve Edebiyat Dergisi, 2/1(22). 51-62.

Datl1, D. (2015). Risâletü'n-Nushiyye'nin birleşik fiil örgüsü. Journal of Turkish Studies, 10(8). 795-817. http://dx.doi.org/10.7827/TurkishStudies.8315

Devellioğlu, F. (2005). Osmanlı Türkçesi sözlüğü. Ankara: Aydın Kitabevi.

Göksel, A. ve Kerslake, C. (2004). Turkish: A comprehensive grammar. Routledge.

Gölpınarlı, A. (1965). Yunus Emre Risalat al-Nushiyya ve Divan. İstanbul: Eskişehir Turizm ve Tanıtma Derneği Yayını.

Gülsevin, G. (1990). Türkçede -sA şart gerundiumu (zarf-fiil) üzerine. Türk Dili, 467, 276-279.

Gülsevin, G. (2001). Türkiye Türkçesinde birleşik zarf-fiiller. Afyon Kocatepe Üniversitesi Sosyal Bilimler Dergisi, 2(2), 125-143.

Gülsevin, G. (2011). Eski Anadolu Türkçesinde ekler. Ankara: TDK.

Gülsevin, G., ve Boz, E. (2004). Eski Anadolu Türkçesi. Ankara: Gazi Kitabevi.

Günay, U. ve Horata O. (2004) Yunus Emre Risâletü'n-Nushiyye. Ankara: Akçağ Yayınevi.

Kamacı Gencer, D. (2019). Dede Korkut kitabında bilgi kipliği. Uluslararası Türkçe Edebiyat Kültür Eğitim (TEKE) Dergisi, 1(8), 38-52. 
Kamacı Gencer, D. (2020). Anlamsal bir fenomen olarak kiplik: Dede Korkut örneği. Ankara: Nobel Yayınları.

Karahan, L. (1994). -sa/-se Eki Hakkında, Türk Dili, 516, 471-474.

Korkmaz, Z. (2009). Türkiye Türkçesi grameri, şekil bilgisi. Ankara: TDK.

Lewis, G. L. (2000). Turkish grammar. Oxford: Oxford University Press.

Mengi, M. (2000). Divan şiiri yazıları (vol. 342). Ankara: Akçağ Yayınları.

Palmer, F. R. (2001). Mood and modality. Cambridge: Cambridge University Press.

Salan, E. (2017). \{-IcAk\} Zarf-fiil eki ve varyantları üzerine. Gazi Türkiyat Türkoloji Araştırmaları Dergisi, 1(21), 45-73.

Saraç, M., A., Y. (2007). Klasik edebiyat bilgisi belâgat. İstanbul: 3F Yayınevi.

Tatc1, M. (2008), Yunus Emre divanı (Tenkitli Metin). İstanbul: H Yayınları.

Tiken, K. (1999). Türkiye Türkçesinde basit ve birleşik zarf-fiillerin ifade ve işlevleri. Türk Dili Araştırmaları Yıllı̆̆g-Belleten, 47, 279-364.

Üstünova, K. (2016). Eylem işletimi. Bursa: Sentez Kitabevi.

Üzüm, M. (2019). Eski Anadolu Türkçesinde epistemik kiplik: Kısas-ı Enbiya örneği, Ankara: Nobel Yayınevi.

Yunus Emre (2012). Risâletü'n-Nushiyye öğüt kitabı, (haz. Prof. Dr. Erdoğan Boz) Ankara: Gazi Kitabevi.

\section{ETIKK ve BİLIMSEL İLKELER SORUMLULUK BEYANI}

$\mathrm{Bu}$ çalışmanın tüm hazırlanma süreçlerinde etik kurallara ve bilimsel atıf gösterme ilkelerine riayet edildiğini yazar(lar) beyan eder. Aksi bir durumun tespiti halinde Afyon Kocatepe Üniversitesi Sosyal Bilimler Dergisi'nin hiçbir sorumluluğu olmayıp, tüm sorumluluk makale yazarlarına aittir. 